\title{
Calcinosis Cutis: Symptomatic Cutaneous Calcium Deposits After Failed Medical Management
}

\author{
Brano Djenic ${ }^{1 *}$, Ross F Goldberg ${ }^{1}$ and Xuan Nguyen ${ }^{2}$ \\ ${ }^{1}$ Department of Surgery, Maricopa Medical Center, USA \\ ${ }^{2}$ Department of Internal Medicine, Division of Dermatology, Maricopa Medical Center, USA
}

Submission: April 25, 2017; Published: May 03, 2017

*Corresponding author: Brano Djenic, Department of Surgery, Maricopa Medical Center, Phoenix, AZ 85008, USA, Tel: 2108630673;

Email: brano.djenic@mihs.org

\section{Introduction}

Calcinosis cutis is a known complication of dermatomyositis. Recurrences of calcinosis cutis are common and once this occurs, there are few successful therapeutics.

\section{Methods}

This is a case report and a review of the literature. This case study was reviewed and approved by IRB. Diagnostic work up, surgical interventions and follow up care were carried out at Maricopa Medical Center, in Phoenix, Arizona, USA.

\section{Case Presentation}
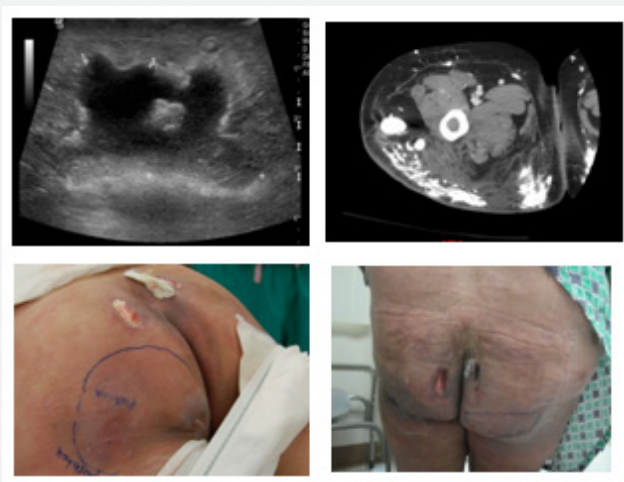

Figure 1: Imaging suggested calcinosis cutis, a $8 \mathrm{~mm}$ punch biopsy showed chalky white liquid material extruding from the wound.

This is a case report of 22 year-old Hispanic woman with dermatomyositis, myositis with calcinosis cutis, history of Reynaud's phenomenon, protein $\mathrm{S}$ deficiencies resulting in requiring the right little finger amputation, and chronic pain syndrome secondary to the dermatomyositis. Patient developed new red, indurated, boggy and painful subcutaneous nodules. Imaging suggested calcinosis cutis, an $8 \mathrm{~mm}$ punch biopsy showed chalky white liquid material extruding from the wound (Figure 1). A surgical consult was obtained for incisions and draining of these various deposits of calcium around her sacral and gluteal musculature that were causing severe pain and substantially affecting her quality of life.

This is a case report of 22 year-old Hispanic woman with dermatomyositis, myositis with calcinosis cutis, history of Reynaud's phenomenon and protein $\mathrm{S}$ deficiencies resulting in right little finger amputation and chronic pain syndrome secondary to the dermatomyositis. Patient developed new red, indurated, boggy and painful subcutaneous nodules. Imaging suggested calcinosis cutis. An $8 \mathrm{~mm}$ punch biopsy showed chalky white liquid material extruding from the wound (Figure 1). A surgical consult was obtained for incision and drainage of these various deposits of calcium around her sacral and gluteal musculature that were causing severe pain and substantially affecting her quality of life (QoL).

Patient was taken to theOR for an incision and drainage of the above mentioned sites. Intra-operatively, the drainage expressed was chalk-like, semi-solid calcium deposits. These were different from the rock-hard solidified calcium deposits that were throughout her body and easily palpated over several joints. The patient has underwent two more surgical drainage procedures of newly developed calcinosis cutis subcutaneous nodules; each time liquid calcium deposits were drained it provided relief from her pain and improved QoL.

Calcinosis cutis is a known complication of dermatomyositis. Recurrences of calcinosis cutis are common and once this occurs, there are few successful therapeutics. The best treatment is to treat the dermatomyositis aggressively but even dermatomyositis can be difficult to treat as in this patient with the various immunosuppressive medications. The calcinosis cutis in this patient has been treated with the following: sodium thiosulfate, calcium channel blockers, promidronate and warfarin. Given the large numbers of lesions, surgical excision was not our first choice in therapeutics. However with the 
introduction of warfarin the calcinosis cutis lesions remain in the liquid state allowing surgical debridement with secondary wound healing have been effective for this patient.

\section{Discussion}

The best treatment for dermatomyositis is aggressive medical management, but dermatomyositis can often be difficult to treat, as in this patient with the various immunosuppressive medications. The calcinosis cutis in this patient has been treated with the following: sodium thiosulfate, calcium channel blockers, promidronate and warfarin. Given the large numbers of lesions, surgical excision was not our first choice in therapeutics. However, with the introduction of warfarin to the regimen, the lesions have remained in the liquid state, thus allowing surgical debridement and effective drainage and symptomatic relief.

Your next submission with Juniper Publishers will reach you the below assets

- Quality Editorial service

- Swift Peer Review

- Reprints availability

- E-prints Service

- Manuscript Podcast for convenient understanding

- Global attainment for your research

- Manuscript accessibility in different formats

( Pdf, E-pub, Full Text, Audio)

- Unceasing customer service

Track the below URL for one-step submission https://juniperpublishers.com/online-submission.php 